\title{
The Influence of Trust on Knowledge Donating and Collecting: An Examination of Malaysian Universities
}

\author{
See-Kwong Goh ${ }^{1} \&$ Manjit-Singh Sandhu ${ }^{2}$ \\ ${ }^{1}$ Taylor's Business School, Taylor's University, Selangor, Malaysia \\ ${ }^{2}$ Department of Management, Monash University, Sunway Campus, Malaysia \\ Correspondence: See-Kwong Goh, Taylor's Business School, Taylor's University, 47500 Selangor, Malaysia. Tel: \\ 603-5629-5658. E-mail: seekwong.goh@taylors.edu.my; goh.seekwong@gmail.com
}

\author{
Received: October 8, 2013 Accepted: November 15, 2013 Online Published: January 24, 2014 \\ doi:10.5539/ies.v7n2p125 URL: http://dx.doi.org/10.5539/ies.v7n2p125
}

\begin{abstract}
The purpose of this research is to examine the influence of affect-based trust and cognition-based trust on knowledge sharing behaviour by adopting the theory of planned behaviour in selected universities in Malaysia. The research adopted survey method and a total of 545 participants from 30 universities. Multiple regression was used to assess the research model. The findings indicate that attitude and subjective norms had positive impact on both knowledge donating and knowledge collecting. However, perceived behavioural control had significant effect on knowledge donating while trust had significant effect on knowledge collecting. Practitioners should focus in developing a climate where academics will have positive attitude and subjective norms towards knowledge sharing as well as a climate of trustworthiness.
\end{abstract}

Keywords: knowledge sharing, trust, education industry, Malaysia

\section{Introduction}

With the advent of globalisation, the business and economic landscape has seen tremendous changes in the way firms compete in recent times. Knowledge has today become a vital factor of production that can enable firms to sustain its competitive advantage in the long run. It is seen as the 'most strategically important resource' that organisations own (Grant, 1996, p. 376). Davenport and Prusak (1998) went one step further by reiterating that knowledge assets are more difficult to imitate and replicate due to its intangibility and is therefore more important than tangible resources. According to previous studies, knowledge sharing helps to increase overall team effectiveness, aid managers to develop better and more accurate decisions (Prahalad \& Hamel, 1990; Zajac \& Bazerman, 1991).

In the context of higher education, knowledge sharing is deemed to be crucial as the core activities of a university are naturally knowledge-centred. These academic institutions are classified as knowledge based organisation where knowledge serves as the core competencies and it lays the foundation of an institution's competitive advantage. A clear example would be sharing technical knowledge among the academic staff could generally or specifically enhance the capability and quality of research undertaken by the universities. It is also a norm and culture in an academic institution that senior academic staffs share knowledge and expertise with junior academics to improve the symbiotic processes of learning and teaching respectively.

Within the Malaysian academic environment, knowledge sharing is not only encouraged, but crucial in achieving academic objectives. More specifically, academic institutions in this region are not as advanced as their western academic counterparts or even Asian countries such as Japan or Korea. In furtherance on seeking knowledge sharing, academic institutions in Malaysia are also seen creating collaborations not only within their academic counterparts but also commercial entities that generally have the funds and infrastructure to facilitate their pursuit of academic research. As a result, it is vital to understand how to initiate and facilitate knowledge sharing behaviour in universities.

Literature has indicated that trustworthiness serves as a crucial component in knowledge sharing (Bakker, Leenders, Gabbay, Krstzer, \& Van Engelen, 2006; Chowdhury, 2005; Hsu, Ju, Yen, \& Chang, 2007). However, there is a dearth in literature about empirical examination on how interpersonal trust affects academics in donating and collecting knowledge. In fact, most of the recent research that examined impact of trust on KS has 
considered it as a one dimensional construct (Al-Alawi, Al-Marzooqi, \& Mohammed, 2007). We argue that there is a need to look at the multidimensional aspect of trust: affect-based trust (ABT) and cognition-based trust (CBT) (Chowdhury, 2005) and its impact on KS behaviour so that a more in depth view can be obtained. Therefore, the study aims to predict the influence of trust towards KS behaviour. We proposed to measure the influence of trust by adopting the theory of planned behaviour as the primary model to predict KS behaviour. The insights obtained from this research will have significant contribution to the education management literature.

\section{Literature Review}

\subsection{Knowledge Sharing Behaviour}

Knowledge sharing is crucial for a firm and it requires effort from all levels. This practise could involve different number of individuals within different levels of the organisation; an individual sharing with another individual e.g. one to one; an individual sharing with a group of people e.g. one to division or department; or an individual sharing with the entire organisation e.g. one to entire company (Argote, Ingram, Levine, \& Moreland, 2000). This process assumes that at least two parties to be involved; one in donating or distributing the knowledge while the other acquires and collects the knowledge (Van den Hooff \& de Ridder, 2004; Vithessonthi, 2008). Similarly, Ardichvili, Page, and Wentling (2003), knowledge sharing requires both sides of providing new knowledge and in requesting for the knowledge. Therefore, this paper adopts the ideology of Van Den Hooff and De Ridder (2004, p. 118) whereby knowledge sharing is divided into "knowledge donating-communicating to others what one's personal intellectual capital is; and knowledge collecting-consulting colleagues in order to get them to share their intellectual capital".

We argue that most past research on knowledge sharing tended to focus on the concept of knowledge transfer which we believe is not synonymous with knowledge sharing since the former looks at the uni directionality or one way transfer (Lok, Hung, \& Fang, 2008, p. 246) of knowledge mainly between HQs and subsidiaries while the latter looks at multiple directionality or two way transfer of knowledge between giver and recipient. This research will focus on knowledge sharing which consist of both knowledge donating and knowledge collecting.

In order to gain a fundamental understanding on how academics share their knowledge, we proposed to adopt the existing theories of social psychology, namely theory of reasoned action (TRA) and the theory of planned behaviour (TPB). Both theories have been adopted to study knowledge sharing behaviour in various context and the findings indicated that both theories are accepted in predicting ones behaviour in knowledge sharing. Later, trust is added into the TPB model as an independent construct in predicting knowledge sharing behaviour.

\subsection{Theory of Reasoned Action}

The name of reasoned action came from the assumption that individuals are reasonable beings and constructively use information in an analytical manner (Fishbein \& Ajzen, 1975). TRA suggests that an individual's behaviour is shaped by the intention (I) to execute or not to execute the behaviour. The likelihood of an individual in participating a specific behaviour $(\mathrm{B}=\mathrm{f}(\mathrm{I}))$ corresponds with the behavioural intention. Based on the past researches, behavioural intention is a good indicator of the targeted behaviour. Due its strong and significant causal link to the targeted behaviour, we proposed to adopt behavioural intention as the dependent variable to examine academics' knowledge sharing. Behavioural intention (BI) is being influenced by two other variables: attitude (A) toward the specific behaviour and the social forces for conforming to certain behaviour, it is also known as subjective norm (SN) (Fishbein \& Ajzen, 1975). This could be represented by a simple equation of BI $=\mathrm{A}+\mathrm{SN}($ Bock \& Kim, 2002; Fishbein \& Ajzen, 1975).

Attitude is described as "the degree to which a person has a favourable or unfavourable evaluation of the behaviour in question" (Ajzen, 1991, p. 188). In other words, attitude assesses an individual's belief and consequences in pursuing a specific behaviour (Bock \& Kim, 2002; So \& Bolloju, 2005). Subjective norm is defined as "the perceived social pressure to perform or not to perform the behaviour" (Ajzen, 1991, p. 188). The past research reviews that this construct is critically influencing behavioural intention (Ajzen \& Fishbein, 1980; Bock \& Kim, 2002; Mathieson, 1991; Goh \& Sandhu 2013). As mentioned earlier, subjective norm evaluates and assesses whether an individual is willing to conform to the surrounding social pressure in its existence to sequentially perform a distinct behaviour. As such, one's intention towards a knowledge sharing behaviour depends largely on the attitude and subjective norms. Based on this argument, we hypothesised:

Hypotheses

1(a): Academic's attitude will have a positive influence over KD intention.

1(b): Academic's attitude will have a positive influence over KC intention. 
2(a): Academic's subjective norm will have a positive influence over KD intention.

2(b): Academic's subjective norm will have a positive influence over $\mathrm{KC}$ intention.

TRA has been applied extensively in the field of social psychology, marketing, applied management, healthcare and technology adoption studies (Chang, 1998; Kolekofski \& Heminger, 2003; Ryu, Ho, \& Han, 2003; Samieh \& Wahba, 2007; Shih \& Farn, 2008). Notwithstanding the expediency of this theory, Sheppard et al. (1988) critically commented that TRA could not accurately predict one's behaviour. The basis of this reasoning that stems from this contention is that TRA did not consider one's volitional control. Albeit one might possess the positive attitude and subjective norm in engaging a specific behaviour, the individual however may not eventually execute the behaviour (Cronan \& Al-Rafee, 2008). As commented by Ajzen and Madden (1986, p. 456 ) in order to obtain an accurate measure of the actual behaviour, it is crucial for researchers to understand to what extent an individual has in controlling over the targeted behaviour. Therefore, Ajzen (1991) has enriched the existing model of TRA with an additional construct of perceived behavioural control and the model is known as Theory of Planned Behaviour (TPB).

\subsection{Theory of Planned Behaviour}

In TPB, perceived behavioural control is defined as "the perceived ease or difficulty of performing the behaviour and it is assumed to reflect past experience as well as anticipated impediments and obstacles" (Ajzen, 1991, p. 188). This construct reflects the controllability of an individual either to act or not to act in a specific behaviour (So \& Bolloju, 2005). The concept of perceived behavioural control is deemed to possess similar characteristics with regards to the concept of perceived self-efficacy by Bandura (1982). It is regarded as the self-judgement done by an individual on his or her capability in achieving a specific goal (Kuo \& Young, 2008). According to Ajzen (1991), perceived behavioural control moves to serve as an antecedent for behavioural intention and the behaviour itself. As such, the higher the control belief in accomplishing a specific task, the higher would be the intention of achieving it. Figure 2.3 depict the model of TPB.

Many researchers have adopted TPB to study knowledge sharing intention and behaviour. For instance, Ryu et al. (2003) adopted TPB to predict physician's intention towards knowledge sharing while So and Bolloju (2005) applied TPB to examine the intention of an individual to share and reuse knowledge in the information system sector. Additionally, Lin and Lee (2004) has applied the whole TPB model to investigate the perceptions of senior managers toward knowledge sharing behaviour. More recently, Kuo and Young (2008) combined the TPB with the theory of action control in estimating knowledge sharing behaviour among the teachers through an internet based system.

Hypotheses

3(a): Academic's perceived behavioural control will have a positive influence over KD intention.

3(b): Academic's perceived behavioural control will have a positive influence over $\mathrm{KC}$ intention.

\subsection{Trust}

In the literature of knowledge sharing, many authors have critically commented that different levels of trust between colleagues would inhibit or steer knowledge sharing behaviour (Foos, Schum, \& Rothenberg, 2006; Goh, 2002; Gruenfeld, Mannix, Williams, \& Neale, 1996; Riege, 2007). In fact, the study of trust has been applied into many different streams of study, such as managing organisational change, information system, online consumer behaviour, job satisfaction, relationship marketing and marketing strategy (Cong \& Chau, 2007; Gefen, Karahanna, \& Straub, 2003; Mayer, Davis, \& Schoorman, 1995; Zaheer, McEvily, \& Perrone, 1998). In the context of knowledge sharing, trust between colleagues fall under the category of interpersonal trust and it could be described as one's eagerness to rely on others' behaviour that results in opportunism (Williams, 2001). Trusting someone would allow one to perceive that the act of the other person would be helpful or at least conceive that the other person will not bring harm to him or her.

Several definitions of trust exist in the literature. For example, McAllister $(1995$, p. 25) define trust as "the extent to which a person is confident in, and willing to act on the basis of the words, actions, and decisions of another". Similarly Remple, Holmes and Zanna (1985, p. 96) defined trust as "feelings of confidence and security in the caring responses of the partner and the strength of the relationship". Based on these definitions, trust is being resulted from confidence and willingness to engage in a strong relationship with another person. If one has confidence and willingness to strengthen the relationship with another person, then he or she is more ready in complying to share knowledge with those they trust. As commented by Davenport and Prusak (1998), trust lies at the central point of knowledge sharing. According to the literature, trust appears to be a multidimensional construct (McAllister, 1995; Barney \& Hansen, 1994; Moorman, Zaltman, \& Deshpande, 
1992). Specifically, interpersonal trust is derived from affective and cognitive components (Lewis \& Weigert, 1985).

These two components of affect-based trust and cognition-based trust have been widely use in organisational studies (McAllister, 1995; Yang, Mossholder, \& Peng, 2009). Affective component evaluates the emotional content of trust which ties the relationship between employees (McAllister, 1995). Explicitly, affect-based trust permits the assessor (the one who judge) to constantly interact with the counterpart (the one being judged) based of positive feelings and emotion (Parayitam \& Dooley, 2007). When the assessor feels emotionally pleasant in the relationship, he or she is more willing to exchange personal information and knowledge (Chowdhury, 2005). Alternatively, cognition-based trust derives from the cognitive analysis of the assessor towards other individual (Chowdhury, 2005). Cognitive analysis includes the evaluation of capability and reliability of the one being assessed by the assessor (McAllister, 1995; Levin \& Cross, 2004). Individuals that being perceived to be highly capable in their work and possess outstanding credential (such as professional recognition, distinguished education background and experiences) are more likely to develop higher cognition-based trust by the assessor (Chowdhury, 2005).

Hypotheses:

4(a): Affect-based trust positively influence one's intention to KD

4(b): Affect-based trust positively influence one's intention to $\mathrm{KC}$

5(a): Cognition-based trust positively influence one's intention to KD

5(b): Cognition-based trust positively influence one's intention to $\mathrm{KC}$

The theoretical framework for this study is depicted in Figure 1. The dependent variables are KD and KC while the independent variables are attitude, subjective norms, perceived behavioural control, affective based trust and cognitive based trust.

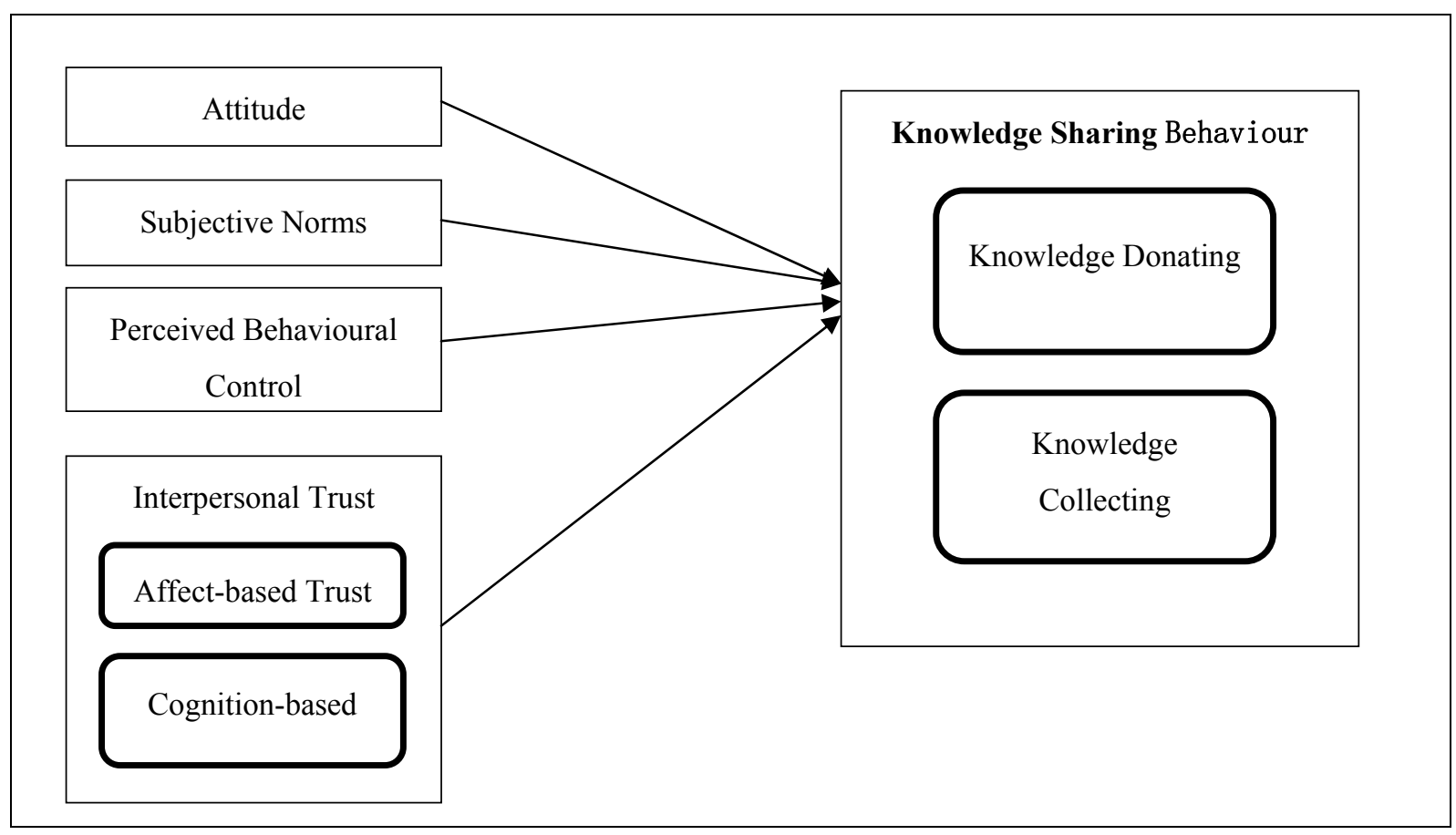

Figure 1. Theoretical framework

\section{Method}

An online survey was conducted to collect data from the respondents in various universities in Malaysia. Sampling strategy followed a few stages where in the first step 30 universities in Malaysia are selected randomly from the Ministry of Higher Education website. Then the staff directory listed on each university's website serves as the sampling frame. The respondents are randomly selected from the respective university website. Only academics were selected. A total of 1,520 email invitations were sent to potential respondents and 78 
emails were rejected due to unforeseen technical problems. It is assumed that the remaining 1,442 emails were successfully mailed to the target respondent. Out of the 1,442 emails, 53 have chosen to opt-out from the research and the remaining 661 people in total responded to the survey. However, only 545 questionnaires were usable due to the fact that 116 were incomplete hence rendering it unusable for the survey. Therefore, the concluding overall response rate is slated at $39.3 \%$.

\subsection{Measurement and Data Collection}

The items for the constructs were adapted from past studies and measured on a 5-point Likert scale; ranging from 1 = strongly disagree, $2=$ disagree, $3=$ neither agree nor disagree, $4=$ agree and $5=$ strongly agree. Table 1 list all the constructs, sources and number of items used.

Table 1. Constructs, item and source

\begin{tabular}{lll}
\hline CONSTRUCT & ITEMS & SOURCE \\
\hline Affective based trust (ABT) & 5 & Yang et al. (2009) \\
Cognitive based trust (CBT) & 5 & Yang et al. (2009) \\
Attitude towards knowledge sharing (ATT) & 4 & Bock et al. (2005) \\
Subjective Norm (SN) & 4 & Bock et al. (2005) \& \\
Kerceived Behavioural Control (PBC) & 6 & $\begin{array}{l}\text { Ryu et al. (2003) } \\
\& \text { Lin (2007) } \\
\text { Van Den Hooff and de Ridder } \\
\text { Knowledge Donating (KD) }\end{array}$ \\
Knowledge Collecting (KC) & 3 & $\begin{array}{l}\text { Van Den Hooff and de Ridder } \\
(2004)\end{array}$ \\
\hline
\end{tabular}

\subsection{Exploratory Factor Analysis}

We conducted the Kaiser-Mayer Olkin's (KMO) measure of sampling adequacy test and Bartlett's test of sphericity to assess the suitability of the survey data for factor analysis (Hair, Black, Babin, Anderson, \& Tatham, 2006). Factor analysis was also useful to determine construct validity: convergent and discriminant validity. The results of the KMO measure of sampling adequacy and Bartlett's test show that the data meet the fundamental requirements for factor analysis. The KMO measure of sampling adequacy is 0.894 and the Bartlett test is highly significant. Factor analysis with principal component analysis and Varimax rotation was then used to group the all the variables into several common factors. The results are reported in Table 2 and 3. In order to control the number of factors extracted, a minimum eigenvalue of one was used in the factor analysis. Factors with eigenvalue less than one were considered insignificant and were excluded. The factor analysis generated seven factors as solution with a total cumulative percentage of variance of $70.83 \%$ and they were found to have meaningful relationships and were therefore, retained. The factors retained are interpreted as follows:

F1: Attitude (ATT); F2: Subjective Norms (SN); F3: Perceived Behavioural Control (PBC); F4: Cognition-based Trust (CBT); F5: Affect-based Trust (ABT). 
Table 2. Factor analysis (Independent variables: TPB and trust)

\begin{tabular}{|c|c|c|c|c|c|}
\hline ITEMS & $\mathrm{F} 1$ & $\mathrm{~F} 2$ & F3 & $\mathrm{F} 4$ & F5 \\
\hline $\begin{array}{l}\text { My knowledge sharing with other organisational members is } \\
\text { good. }\end{array}$ & .666 & & & & \\
\hline $\begin{array}{l}\text { My knowledge sharing with other organisational members is } \\
\text { an enjoyable experience. }\end{array}$ & .786 & & & & \\
\hline $\begin{array}{l}\text { My knowledge sharing with other organisational members is } \\
\text { valuable to me. }\end{array}$ & .742 & & & & \\
\hline $\begin{array}{l}\text { My knowledge sharing with other organisational members is a } \\
\text { wise move. }\end{array}$ & .719 & & & & \\
\hline $\begin{array}{l}\text { My CEO/Principal/Vice Chancellor thinks that I should share } \\
\text { my knowledge with other members in the organisation. }\end{array}$ & & .825 & & & \\
\hline $\begin{array}{l}\text { My boss thinks that I should share my knowledge with other } \\
\text { members in the organisation. }\end{array}$ & & .813 & & & \\
\hline $\begin{array}{l}\text { My colleagues think I should share my knowledge with other } \\
\text { members in the organisation. }\end{array}$ & & .764 & & & \\
\hline $\begin{array}{l}\text { My peers in my field of expertise think I should share my } \\
\text { knowledge with other members in the organisation. }\end{array}$ & & .700 & & & \\
\hline For me to share my knowledge is always possible. & & & .680 & & \\
\hline If I want, I always could share knowledge. & & & .736 & & \\
\hline It is mostly up to me whether or not I share knowledge. & & & .833 & & \\
\hline $\begin{array}{l}\text { I believe that I have much control to share my knowledge } \\
\text { with others. }\end{array}$ & & & .817 & & \\
\hline $\begin{array}{l}\text { I am confident in my ability to provide knowledge that others } \\
\text { in my company consider valuable. }\end{array}$ & & & .575 & & \\
\hline $\begin{array}{l}\text { I have the expertise required to provide valuable knowledge } \\
\text { for my company. }\end{array}$ & & & .470 & & \\
\hline I can depend on my colleague to meet his/her responsibilities. & & & & .818 & \\
\hline I can rely on my colleague to do what is best at work. & & & & .847 & \\
\hline $\begin{array}{l}\text { My colleague follows through with commitments he/she } \\
\text { makes. }\end{array}$ & & & & .832 & \\
\hline $\begin{array}{l}\text { Given my colleague's track record, I see no reason to doubt } \\
\text { his/her competence. }\end{array}$ & & & & .785 & \\
\hline $\begin{array}{l}\text { I'm confident in my colleague because (s)he approaches work } \\
\text { with professionalism. }\end{array}$ & & & & .800 & \\
\hline $\begin{array}{l}\text { I'm confident that my colleague will always care about my } \\
\text { personal needs at work. }\end{array}$ & & & & & .542 \\
\hline $\begin{array}{l}\text { If I shared my problems with my colleague, I know (s)he } \\
\text { would respond with care. }\end{array}$ & & & & & .637 \\
\hline $\begin{array}{l}\text { I'm confident that I could share my work difficulties with my } \\
\text { colleague. }\end{array}$ & & & & & .638 \\
\hline $\begin{array}{l}\text { I'm sure I could openly communicate my feelings to my } \\
\text { colleague. }\end{array}$ & & & & & .767 \\
\hline I feel secure with my colleague because of his/her sincerity. & & & & & .650 \\
\hline
\end{tabular}

F6: Knowledge Donating (KD); F7: Knowledge Collecting (KC). 
Table 3. Factor analysis (Dependent variables: $\mathrm{KD}$ and $\mathrm{KC}$ )

\begin{tabular}{llll}
\hline ITEMS & F6 & F7 \\
\hline $\begin{array}{l}\text { When I have learned something new, I see to it that } \\
\text { colleagues outside of my department can learn it as well. }\end{array}$ & & \\
$\begin{array}{l}\text { I share the information I have with colleagues outside of my } \\
\text { department. }\end{array}$ & .891 & \\
I share my skills with colleagues outside of my department. & .881 & \\
Colleagues within my department tell me what they know, & & .766 \\
when I ask them about it. & \\
$\begin{array}{l}\text { Colleagues within my department tell me what their skills } \\
\text { are, when I ask them about it. }\end{array}$ & .750 \\
$\begin{array}{l}\text { Colleagues outside of my department tell me what they } \\
\text { know, when I ask them about it. }\end{array}$ & .814 \\
$\begin{array}{l}\text { Colleagues outside of my department tell me what their } \\
\text { skills are, when I ask them about it. }\end{array}$ & .782 \\
\hline
\end{tabular}

\subsection{Reliability Test}

A Cronbach coefficient alpha test was conducted on all the seven factors (5 Independent Variables and 2 Dependent Variables) to test the reliability of all the item variables. This was to determine the internal consistency of the scale used. The values of Cronbach Alpha coefficient are depicted below in Table 3. All the factors were found to have alpha coefficient values of greater than 0.7 which is an acceptable level of reliability (Hair et al., 2006).

Table 4. Reliability tests

\begin{tabular}{ll}
\hline FACTORS & CRONBACH ALPHA VALUES \\
\hline Attitude & 0.832 \\
Subjective norms & 0.866 \\
Perceived behavioural control & 0.832 \\
Cognitive trust & 0.922 \\
Affective trust & 0.908 \\
Knowledge donating & 0.840 \\
Knowledge collecting & 0.874 \\
\hline
\end{tabular}

\section{Results}

\subsection{Respondents' Profile}

The study population consisted of academics in 30 different universities in Malaysia. About $45 \%$ of the respondents were male and 55\% of them were female. There is a good mixture of public and private universities where both equally share $50 \%$ of the respondents. The average age of respondent is 37 years old and about $93 \%$ of the respondents had postgraduate qualifications. Majority of the respondents held a lecturer position (58\%) followed by $29 \%$ of them were senior lecturers and about $13 \%$ at Professor and Associate Professor level.

\subsection{Descriptive Statistics and Analysis}

Table 4 lists down all the descriptive statistics (means, standard deviations and bivariate correlations) involving both the dependent and independent variables. A closer examination of the mean scores reveals that generally, academics are very positive towards sharing of knowledge in universities. The highest mean score was obtained for PBC (4.10) whereas the lowest mean score was obtained for ABT (3.57). All correlations were significant at $\mathrm{p}<0.01$ 
Table 5. Descriptive statistics

\begin{tabular}{|c|c|c|c|c|c|c|c|c|c|}
\hline \multicolumn{2}{|c|}{ Variable } & Means & SD & 1 & 2 & 3 & 4 & 5 & 6 \\
\hline 1 & ATT & 3.91 & 0.48 & & & & & & \\
\hline 2 & SN & 3.80 & 0.60 & $.533^{* *}$ & & & & & \\
\hline 3 & PBC & 4.10 & 0.47 & $.495^{* *}$ & $.312^{* *}$ & & & & \\
\hline 4 & $\mathrm{ABT}$ & 3.57 & 0.66 & $.380^{* *}$ & $.384^{* *}$ & $.255^{* *}$ & & & \\
\hline 5 & CBT & 3.67 & 0.63 & $.329^{* *}$ & $.332^{* *}$ & $.252^{* *}$ & $.738^{* *}$ & & \\
\hline 6 & KD & 3.73 & 0.59 & $.403^{* *}$ & $.390^{* *}$ & $.302^{* *}$ & $.266^{* *}$ & $.229^{* *}$ & \\
\hline 7 & $\mathrm{KC}$ & 3.70 & 0.54 & $.423^{* *}$ & $.489^{* *}$ & $.275^{* *}$ & $.510^{* *}$ & $.490^{* *}$ & $.471^{* *}$ \\
\hline
\end{tabular}

$\mathrm{N}=545$; *correlation is significant at the 0.01 level (1- tailed).

\subsection{Regression Analysis}

In order to examine the hypotheses, regression analysis was adopted. The results of the regression analysis are shown in Table 5 and 6 respectively. To test for multicollinearity, variance inflation factor (VIF) values were examined and all were found to be below 2.5 which means there is low multi-collinearity among the independent variables and the stability of the regression was not affected (Hair et al., 2006). Model 1 provides regression results on the impact of $\mathrm{ATT}, \mathrm{SN}, \mathrm{PBC}, \mathrm{ABT}$ and $\mathrm{CBT}$ on $\mathrm{KD}$ and Model 2 provides regression results on the impact of ATT, SN, PBC, ABT and CBT on KC.

Table 6. Model 1: regression results on the impact of ATT, SN, PBC, ABT and CBT on KD

\begin{tabular}{lllll}
\hline Independent variables & Beta Coefficient & t-value & p-value & VIF \\
\hline Constant & 1.11 & 4.82 & $0.00^{* *}$ & \\
ATT & 0.25 & 4.01 & $0.00^{* *}$ & 1.73 \\
SN & 0.21 & 4.70 & $0.00^{* *}$ & 1.48 \\
PBC & 0.14 & 2.61 & $0.01^{* *}$ & 1.34 \\
ABT & 0.06 & 1.20 & 0.23 & 2.34 \\
CBT & 0.01 & 0.18 & 0.86 & 2.22 \\
\hline
\end{tabular}

$\mathrm{R}^{2}=0.214, \mathrm{~F}=30.641$

$\mathrm{Sig}=0.000$;

$* * \mathrm{p}<0.01,(\mathrm{~N}=545)$.

The result in Table 5 shows that as hypothesised, three constructs of TPB (ATT, SN \& PBC) had significant positive influence on KD. H1a, H2a and H3a were therefore supported. Contrary, ABT and CBT had positive insignificant influence on KD. $\mathrm{R}^{2}$ value of 0.214 showed that $21 \%$ of the variation in KD is explained by the by ATT, SN and PBC. A closer examination of the regression results reveals that ATT had the highest impact on KD $($ Beta $=0.25)$ followed by SN $($ Beta $=0.21)$. 
Table 7. Model 2: regression results on the impact of ATT, SN, PBC, ABT and CBT on KC

\begin{tabular}{lllll}
\hline Independent variables & Beta Coefficient & t-value & p-value & VIF \\
\hline Constant & 0.89 & 4.803 & $0.00^{* *}$ & \\
ATT & 0.14 & 2.765 & $0.01^{* *}$ & 1.73 \\
SN & 0.24 & 6.603 & $0.00^{* *}$ & 1.48 \\
PBC & 0.03 & 0.708 & 0.48 & 1.34 \\
ABT & 0.17 & 3.966 & $0.00^{* *}$ & 2.34 \\
CBT & 0.17 & 4.055 & $0.00^{* *}$ & 2.22 \\
\hline
\end{tabular}

$\mathrm{R}^{2}=0.388, \mathrm{~F}=70.088$;

Sig $=0.000$;

$* * \mathrm{p}<0.01,(\mathrm{~N}=545)$.

The result in Table 6 shows that as hypothesised, two constructs of TPB (ATT \& SN) and trust (ABT \& CBT) had significant positive influence on KC. H1b, H2b, H4b and H5b were therefore supported. Contrary, PBC had positive insignificant influence on KC. $\mathrm{R}^{2}$ value of 0.388 showed that $39 \%$ of the variation in $\mathrm{KD}$ is explained by the by ATT, SN, ABT and CBT. A closer examination of the regression results reveals that $\mathrm{SN}$ had the highest impact on $\mathrm{KC}(\mathrm{Beta}=0.24)$ followed by trust $(\mathrm{ABT}$ : Beta $=0.17 \& \mathrm{CBT}$ : Beta $=0.17)$.

\section{Discussion}

The main purpose of this paper is to examine the impact of TPB and trust towards KS behaviour among the academics in Malaysia. The findings above indicate interesting and mixed results. Overall, the results indicated a good fit to the data and seven hypotheses were supported. As hypothesised, attitude and subjective norms were found to have significant positive relationship towards knowledge donating and knowledge collecting. Meanwhile, perceived behavioural control was found to have a positive significant relationship with knowledge donating and not knowledge collecting. Trust was found to have significant relationship with knowledge collecting and insignificant relationship with knowledge donating.

The findings of this research are in line with some past researches (Bock et al., 2005; Hsu \& Lin, 2008; Lin \& Lee, 2004) where attitudes and subjective norms played a critical role in knowledge sharing behaviour. However, perceived behavioural control is found to be significant for knowledge donating and not knowledge collecting. This indicates that TPB is only useful to predict one's knowledge donating and not knowledge collecting. Conversely, trust plays a significant role in knowledge collecting and not knowledge donating. Moreover, the influence of attitude is higher in knowledge donating $(25 \%>14 \%)$ than knowledge collecting. This indicates that attitude varies in different categories of knowledge sharing activities. In order for one to donate his or her knowledge, that individual must first develop a positive evaluation towards knowledge sharing. Otherwise academics are less likely to donate their knowledge.

In the context of Malaysian universities, one's intention to donate knowledge to other academics rely heavily on the positive attitude evaluation, social pressure and the perception of self efficacy in sharing his or her knowledge. Trust between colleagues did not play a vital role in donating one's knowledge. This could be due to the job nature of academics that frequently channel their intellectual capital to others, regardless of who the target audience is. In addition, this phenomenon could also be due to the less competitive climate in the academia world where academics felt that sharing knowledge to others will not threaten their position. In fact, the academics are more concern as to whether they have the capability to channel the knowledge to others. In this situation, administrators of a university have to encourage and appreciate academics to participate in knowledge sharing activity by promoting open communication, create working teams to share ideas, encourage feedback and discussion.

On the other hand, trust plays a crucial role in getting others to share their knowledge. Academics perceived that getting their colleagues to share their knowledge requires strong social bonding such as trust. In other words, if one does not trust another colleague, he or she will not seek knowledge from him or her. In order to encourage consistent flow of knowledge within the university, the management needs to increase the level of trust and instil stronger social ties between academics. This situation is exceptionally critical for young or new academics as they might not approach the senior staff if they do not have strong bonding with them. 
This study consists of a few limitations. First, the findings of this research have to be interpreted with distinct parameters and considerations as the sample adopted in this research is purely based on the context of universities in Malaysia. Consequently the results are industry specific with reference to the academia world and would unlikely be readily applicable to other industries. In order to increase the generalisability of the findings, future research could involve different industries. It should also be noted that the research adopts a cross sectional study instead of longitudinal study. Cross sectional research might not be able to capture the perception of knowledge sharing behaviour across a period of time. Nevertheless, having made this statement, a majority of the relationship posited were based on the grounded findings from past research. Future studies should also examine whether personal and demographic factors such as gender, ethnicity, job position, type of industry, country of origin will moderate the impact of affect-based trust and cognition-based trust on knowledge donating and knowledge collecting.

\section{References}

Ajzen, I. (1991). The Theory of Planned Behavior. Organizational Behavior and Human Decision Processes, 50(2), 179-211. http://dx.doi.org/10.1016/0749-5978(91)90020-T

Ajzen, I., \& Fishbein, M. (1980). Understanding attitudes and predicting social behavior. Englewood Cliffs, NJ: Prentice-Hall.

Ajzen, I., \& Madden, T. J. (1986). Prediction of Goal-Directed Behavior: Attitudes, intentions, and perceived behavioral control. Journal of Experimental Social Psychology, 22(5), 453-474. http://dx.doi.org/10.1016/0022-1031(86)90045-4

Al-Alawi, A. I., Al-Marzooqi, N. Y., \& Mohammed, Y. F. (2007). Organizational Culture and Knowledge Sharing: Critical success factors. Journal of Knowledge Management, 11(2), 22-42. http://dx.doi.org/10.1108/13673270710738898

Ardichvili, A., Page, V., \& Wentling, T. (2003). Motivation and Barriers to Participation in Virtual Knowledge-Sharing Communities of Practice. Journal of Knowledge Management, 7(1), 64-77. http://dx.doi.org/10.1108/13673270310463626

Argote, L., Ingram, P., Levine, J. M., \& Moreland, R. L. (2000). Knowledge Transfer in Organizations: Learning from the experience of others. Organizational Behavior and Human Decision Processes, 82(1), 1-8. http://dx.doi.org/10.1006/obhd.2000.2883

Bakker, M., Leenders, R. T., Gabbay, S. S., Krstzer, J., \& Van Engelen, J. M. L. (2006). Is trust really social capital? Knowledge sharing in product development projects. The Learning Organisation, 13(6), 594-605. http://dx.doi.org/10.1108/09696470610705479

Bandura, A. (1982). Self-efficacy Mechanism in Human Agency. American Psychologist, 37(2), 122-147. http://dx.doi.org/10.1037/0003-066X.37.2.122

Barney, J. B., \& Hansen, M. H. (1994). Trustworthiness as a Source of Competitive Advantage. Strategic Management Journal, 15 (Special Issue), 175-190. http://dx.doi.org/10.1002/smj.4250150912

Bock, G. W., \& Kim, Y. G. (2002). Breaking the Myths of Rewards: An exploratory study of attitudes about knowledge sharing. Information Resources Management Journal, 15(2), 14-21. http://dx.doi.org/10.4018/irmj.2002040102

Bock, G. W., Zmud, R. W., Kim, Y. G., \& Lee, J. N. (2005). Behavioral Intention Formation in Knowledge Sharing: Roles of extrinsic motivators, social-psychological forces, and organizational climate. MIS Quarterly, 29(1), 87-112.

Chang, M. K. (1998). Predicting Unethical Behavior: A comparison of the theory of reasoned action and the theory of planned behavior. Journal of Business Ethics, 17(16), 1825-1834. http://dx.doi.org/10.1023/A:1005721401993

Chowdhury, S. (2005). The Role of Affect- and Cognition-based Trust in Complex Knowledge Sharing. Journal of Managerial Issues, 17(3), 310-326.

Cong, Q., \& Chau, P. Y. K. (2007). Does Interpersonal Trust Also Matter? Exploring the Role of Trust in Successful IT Outsourcing. Paper presented at the Proceedings of the 40th Hawaii International Conference on System Sciences, Hawaii.

Cronan, T. P., \& Al-Rafee, S. (2008). Factors that Influence the Intention to Pirate Software and Media. Journal of Business Ethics, 78(4), 527-545. http://dx.doi.org/10.1007/s10551-007-9366-8 
Davenport, H. T., \& Prusak, L. (1998). Working Knowledge: How Organizations Manage What They Know. Boston, MA.: Harvard Business School Press.

Fishbein, M., \& Ajzen, I. (1975). Beliefs, Attitude, Intention and Behavior: An introduction to theory and research. Reading, MA: Addison-Wesley Publishing Company.

Foos, T., Schum, G., \& Rothenberg, S. (2006). Tacit Knowledge Transfer and the Knowledge Disconnect. Journal of Knowledge Management, 10(1), 6-18. http://dx.doi.org/10.1108/13673270610650067

Gefen, D., Karahanna, E., \& Straub, D. W. (2003). Trust and TAM in Online Shopping: an integrated model. MIS Quarterly, 27(1), 51-90.

Goh, S. C. (2002). Managing Effective Knowledge Transfer: An integrative framework and some practice $\begin{array}{llll}\text { implications. Journal of Knowledge } & \text { Management, } & 6(1), & \text { 23-30. }\end{array}$ http://dx.doi.org/10.1108/13673270210417664

Goh, S. K., \& Sandhu, M. S. (2013). Affiliation, Reciprocal Relationships and Peer Pressure in Knowledge Sharing in Public Universities in Malaysia. Asian Social Science, 9(7), 290. http://dx.doi.org/10.5539/ass.v9n7p290

Grant, R. M. (1996). Toward a Knowledge-Based Theory of the Firm. Strategic Management Journal, 17(Winter Speical Issue), 109-122.

Gruenfeld, D. H., Mannix, E. A., Williams, K. Y., \& Neale, M. A. (1996). Group Composition and Decision Making: How member familiarity and information distribution affect process and performance. Organizational Behavior and Human Decision Process, 67(1), 1-15. http://dx.doi.org/10.1006/obhd.1996.0061

Hair, J. F., Black, W. C., Babin, B. J., Anderson, R. E., \& Tatham, R. L. (2006). Multivariate Data Analysis (2nd ed.). New Jersey: Pearson Prentice Hall.

Hsu, C. L., \& Lin, J. C. C. (2008). Acceptance of Blog Usage: The roles of technology acceptance, social influence and knowledge sharing motivation. Information \& Management, 45(1), 65-74. http://dx.doi.org/10.1016/j.im.2007.11.001

Hsu, M., Ju, T., Yen, C., \& Chang, C. (2007). Knowledge Sharing Behaviour In Virtual Communities: the relationship between trust, self-efficacy, and outcome expectation. Journal of Human-Computer Studies, 65(2), 153-169. http://dx.doi.org/10.1016/j.ijhcs.2006.09.003

Kolekofski, K. E., \& Heminger, A. R. (2003). Beliefs and Attitudes Affecting Intentions to Share Information in an Organizational Setting. Information \& Management, 40(6), 521-532. http://dx.doi.org/10.1016/S0378-7206(02)00068-X

Kuo, F. Y., \& Young, M. L. (2008). A Study of Intention-Action Gap in Knowledge Sharing Practices. Journal of the American Society for Information Science and Technology, 59(8), 1224-1237. http://dx.doi.org/10.1002/asi.20816

Levin, D. Z., \& Cross, R. (2004). The Strength of Weak Ties You Can Trust: The mediating role of trust in

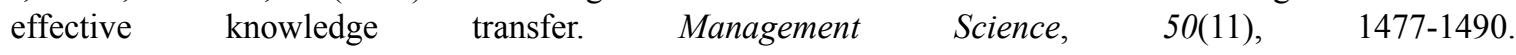
http://dx.doi.org/10.1287/mnsc.1030.0136

Lewis, J. D., \& Weigert, A. (1985). Trust as a Social Reality. Social Forces, 63(4), 967-984.

Lin, H. (2007). Knowledge Sharing and Firm Innovation Capability: An empirical study. International Journal of Manpower, 28(3/4), 315-332. http://dx.doi.org/10.1108/01437720710755272

Lin, H. F., \& Lee, G. G. (2004). Perceptions of Senior Managers Toward Knowledge-sharing Behaviour. Management Decision, 42(1), 108-125. http://dx.doi.org/10.1108/00251740410510181

Lok, P. J., Hung, R. Y. Y., \& Fang, S. C. (2008). An integrative model of organizational learning and social capital on effective knowledge transfer and perceived organizational performance. Journal of Workplace learning, 20(4), 245-258. http://dx.doi.org/10.1108/13665620810871105

Mathieson, K. (1991). Predicting User Intentions: comparing the technology acceptance model with the theory of planned behavior. Information Systems Research, 2(3), 173-191. http://dx.doi.org/10.1287/isre.2.3.173

Mayer, R. C., Davis, J. H., \& Schoorman, F. D. (1995). An Integrative Model of Organizational Trust. Academy of Management Review, 20(3), 709-734.

McAllister, D. J. (1995). Affect- and Cognition-based Trust as Foundations for Interpersonal Cooperation in 
Organizations. Academy of Management Journal, 38(1), 24-59. http://dx.doi.org/10.2307/256727

Moorman, C., Zaltman, G., \& Deshpande, R. (1992). Relationships Between Providers and Users of Market Research: The dynamics of trust within and between organizations. Journal of Marketing Research, 29(August), 314-328. http://dx.doi.org/10.2307/3172742

Parayitam, S., \& Dooley, R. S. (2007). The Relationship between Conflict and Decision Outcomes: Moderating effects of cognitive- and affect-based trust in strategic decision-making teams. International Journal of Conflict Management, 18(1), 42-73. http://dx.doi.org/10.1108/10444060710759318

Prahalad, C. K., \& Hamel, G. (1990). The Core Competence of the Corporation. Harvard Business Review, 68(3), 79-91.

Remple, J. K., Holmes, J. G., \& Zanna, M. D. (1985). Trust in Close Relationships. Journal of Personality and Social Psychology, 49(1), 95-112. http://dx.doi.org/10.1037/0022-3514.49.1.95

Riege, A. (2007). Actions to Overcome Knowledge Transfer Barriers in MNCs. Journal of Knowledge Management, 11(1), 48-67. http://dx.doi.org/10.1108/13673270710728231

Ryu, S., Ho, S. H., \& Han, I. (2003). Knowledge Sharing Behavior of Physicians in Hospitals. Expert Systems with Applications, 25(1), 113-122. http://dx.doi.org/10.1016/S0957-4174(03)00011-3

Samieh, H. M., \& Wahba, K. (2007). Knowledge Sharing Behavior From Game Theory And Socio-Psychology Perspectives. Paper presented at the Proceedings of the 40th Hawaii International Conference on System Sciences, Hawaii.

Sheppard, B. H., Hartwick, J., \& Warshaw, P. R. (1988). The Theory of Reasoned Action: A meta-analysis of past research with recommendations for modifications and future research. Journal of Consumer Research, 15(3), 325-343. http://dx.doi.org/10.1086/209170

Shih, J. C., \& Farn, C. K. (2008). Behavior and Social Influence in Knowledge Sharing: intention formation and the moderating role of knowledge type. Paper presented at the Proceedings of the 7th International Conference on Practical Aspects of Knowledge Management, Yokohama. http://dx.doi.org/10.1007/978-3-540-89447-6_3

So, J. C. F., \& Bolloju, N. (2005). Explaining the Intention to Share and Reuse Knowledge in the Context of IT Service Operations. Journal of Knowledge Management, 9(6), 30-41. http://dx.doi.org/10.1108/13673270510629945

Van den Hooff, B., \& de Ridder, J. A. (2004). Knowledge Sharing in Context: The influence of organizational commitment, communication climate and CMC use on knowledge sharing. Journal of Knowledge Management, 8(6), 117-130. http://dx.doi.org/10.1108/13673270410567675

Vithessonthi, C. (2008). Social Interaction and Knowledge Sharing Behaviors in Multinational Corporations. The Business Review, Cambridge, 10(2), 324-331.

Williams, M. (2001). In Whom We Trust: Group membership as an affective context for trust development. Academy of Management Review, 26(3), 377-397.

Yang, J., Mossholder, K. W., \& Peng, T. K. (2009). Supervisory Procedural Justice Effects: The mediating roles of cognitive and affective trust. Leadership Quarterly, 20(2), 143-154. http://dx.doi.org/10.1016/j.leaqua.2009.01.009

Zaheer, A., McEvily, B., \& Perrone, V. (1998). Does Trust Matter? Exploring the Effects on Inter-organizational and Interpersonal Trust on Performance. Organization Science, 9(2), 141-159. http://dx.doi.org/10.1287/orsc.9.2.141

Zajac, E. J., \& Bazerman, M. H. (1991). Blind Spots in Industry and Competitor Analysis: Implication of interfirm (mis)perceptions for strategic decisions. Academy of Management Review, 16(1), 37-56.

\section{Copyrights}

Copyright for this article is retained by the author(s), with first publication rights granted to the journal.

This is an open-access article distributed under the terms and conditions of the Creative Commons Attribution license (http://creativecommons.org/licenses/by/3.0/). 